\title{
EFEKTIFITAS KELAS NENEK TERHADAP KEBERHASILAN ASI EKSKLUSIF UNTUK MENCEGAH STUNTING
}

\author{
Wahida Yuliana ${ }^{1)}$, Bawon Nulhakim ${ }^{2)}$ \\ Prodi DIII Kebidanan STIKes Hafshawaty Pesantren Zainul Hasan \\ e-mail: wahidayuliana44@gmail.com
}

\begin{abstract}
Abstrak
Nenek merupakan bagian dari keluarga yang juga memberikan pengaruh dalam mendukung kesuksesasan ibu dalam pemenuhan nutrisi bayi. Kelas nenek menjadi pendukung ASI dengan memberi solusi terhadap permasalahan dalam keberhasilan ASI Eksklusif ASI eksklusif merupakan salah satu cara dalam mengatasi stunting dengan manfaatnya yang beragam. Kejadian Stunting di kabupaten probolinggo mencapai 49,43\% dan studi pendahuluan dari hasil penelitian sebelumnya menyebutkan dengan kelas calon nenek berhasil meningkatkan jumlah ibu menyusui hari ke1-3. Tujuan dari penelitian ini adalah mengetahui efektifitas kelas nenek terhadap keberhasilan ASI eksklusif.Penelitian ini merupakan jenis eksperimen dengan membandingkan kelompok control dan kelompok perlakuan. Kelompok control berjumlah 30 ibu balita berusia 4-5 bulan yang memiliki nenek dan kelompok perlakuan juga berjumlah 30 ibu balita yang memiliki nenek yang mengikuti kelas nenek. Instrument penelitian yang digunakan adalaj lembar observasi dan untuk melenghkapi kebutuhan data ditambah dengan wawancara. Analisis yang digunakan adalah chi-square dengan tingkat kemaknaan 95\% (alpha 0,05) dan hasil penelitian didapatkan kelompok yang mendapatkan perlakuan kelas nenek, memberikan ASI Eksklusif sejumlah 20 (66\%) dan kelompok yang tidak mendapatkan perlakuan sejumlah 6 (20\%). Value 0,00< 0,05 menunjukkan kelas nenek berpengaruh dalam pemberian ASI Eksklusif sehingga kelas nenek ini juga dapat menjadi salah satu solusi dalam meningkatkan capai asi eksklusif melalui dukungan keluarga.
\end{abstract}

Kata kunci : ASI eksklusif, kelas nenek

\begin{abstract}
Grandmother classes support ASI by providing solutions to problems in the success of exclusive ASI Exclusive breastfeeding is one way to overcome stunting with a variety of benefits. The incidence of Stunting in Probolinggo regency reached $49.43 \%$ and a preliminary study from the results of previous studies mentioned that the class of prospective grandmothers succeeded in increasing the number of breastfeeding mothers on day 1-3. The purpose of this study is to determine the effectiveness of the grandmother's class on the success of exclusive breastfeeding. This research is a type of experiment by comparing the control group and the treatment group. The control group consisted of 30 mothers of toddlers aged 4-5 months who had grandmothers and the treatment group also numbered 30 mothers of toddlers who had grandmothers who attended grandmother classes. The research instrument used was the observation sheet and to complete the data needs coupled with interviews. The analysis used was chi-square with a significance level of 95\% (alpha 0.05) and the results of the study found that the group that received grandmother treatment, gave 20 (66\%) exclusive breastfeeding and the group that did not get treatment was $6(20 \%)$. Value $0,00<\alpha 0,05$ shows that grandmother's class influences exclusive breastfeeding so that this grandmother class can also be one of the solutions in increasing exclusive breastfeeding through family support.
\end{abstract}

Keywords : ASI exclusive, grandmother classes 


\section{PENDAHULUAN}

Kelas nenek merupakan kelas yang berisikan kelompok nenek yang memiliki balita usia 4-5 bulan untuk kegiatan mendukung Pemberian ASI eksklusif oleh ibu. Nenek dijadikan salah satu pendukung ASI dari dukungan keluarga karena peran keluarga dalam memberikan motivasi, menentukan solusi permasalahan ASi dan penentu keputusan pemberian ASI Eksklusif (Susilo, dkk., 2012)

Cakupan pemberian ASI eksklusif pada bayi umur 0-6 bulan tahun 2015 di Jawa Timur 74,1 \% dan tahun 2016 menurun menjadi 31,3\% (Direktorat Gizi masyarakat, Direktorat jendral kesehatan masyarakat \& kementrian kesehatan RI, 2016). Angka tertinggi prevalensi stunting di Jawa Timur tahun 2017. Pada ranking 10 ada Kabupaten Kabupaten Probolinggo dengan prevalensi balita stunting sebesar $49,43 \%$ (PERSAGI), 2017).

Penelitian yang menhubungkan kelompok pendukung ibu terhadapa pengetahuan dan praktik pemberian ASI eksklusif dapat dijadikan penguat dalam melakukan penelitian terkait kelompok kelompok pendukung. Hasil dari penelitian $7,70 \%$ ibu merasa ASI tidak mencukupi pada kelompok yang mendapat dukungan dan non kelompok pendukung sebanyak $17,40 \%$ ibu merasa ASI tidak cukup dan sangat berpotensi untuk tidak melakukan ASI Eksklusif (Susilo, dkk., 2012)

Penelitian yang pernah dilakukan dalam mengembang penelitian ini adalah penelitian dengan judul efektifitas kelas calon nenek terhadap keberhasilan ASI eksklusif hari ke1-3. Penelitian ini dilakukan pada ibu hamil trimester tiga dengan memberikan kelas pada calon nenek dan melihat saat persalinan sampai hari ke 3 apakah nenek memberikan dukungan dan didapatkan $80 \%$ memberikan ASI Eksklusif dengan percaya diri saat ASI yang dikeluarkan pada hari 1-3. (Yuliana,Dkk,2018)

Program terkait memberdayakan masyarakat sangat diperlukan untuk keberhasilan capaian ASI Eksklusif. Kelas nenek dapat dijadikan salah satu upaya untuk bisa mencapai target ASI Eksklusif.

Tujuan dari Penelitian ini adalah ingin mengetahui efektifitas kelas nenek terhadap keberhasil ASI Ekksklusif dengan hipotesa kelas nenek efektif dalam keberhasilan ASI Eksklusif.

\section{METODE PENELITIAN}

Jenis penelitian ini adalah Quasyexperiemental yang merupakan bentuk desain eksperimen (Hidayat, 2009). Rancangan penelitian yang digunakan adalah Quasy experiment with post test only nonequivalent control grup design. Rancangan ini berupaya untuk mengungkapkan hubungan sebab akibat dengan cara melibatkan kelompok kontrol disamping kelompok eksperimental (Nursalam, 2008). Populasi dari penelitian ini adalah ibu bayi berusia 4-5 bulan beserta neneknya.Teknik sampling yang digunakan adalah purposive sampling dengan jumlah sample 30 untuk control dan 30 responden yang mendapatkan perlakuan.Instrumen penelitian menggunakan lembar observasi dan wawancara. Analisis data bivariat menggunakan chi-square.

Penelitian ini diawali dengan kelompok control artinya peneliti tidak melakukan perlakuan terhadap nenek dengan tidak membuka kelas nenek. Sample dilakukan skrining dan dipantau melalui lembar observasi untuk melihat dilakukan ASI ekslusif atau tidak.Setelah 30 orang terpenuhi maka selanjutnya melakukan perlakuan pada kelompok perlakuan dengan mengadakan kelas nenek bagi 30 responden selanjutnya dan kemudian dievaluasi hasil kegiatan dengan melihat diberiakn $\mathrm{ASi}$ eksklusif atau tidak.

\section{HASIL DAN PEMBAHASAN}

\section{Hasil}

Analisis univariat bertujuan untuk mendeskripsikan karakteristik dari subyek penelitian. Hasil analisis univariat yang dilihat dari beberapa variable didapatkan gambaran karakteristik subyek penelitian. 
Tabel 1. Karakteristik Responden

\begin{tabular}{|c|c|c|}
\hline Variabel & Frekuensi & Prosentase \\
\hline \multicolumn{3}{|l|}{ Kelompok } \\
\hline Kelas nenek & 30 & $50 \%$ \\
\hline kontrol & 30 & $50 \%$ \\
\hline \multicolumn{3}{|l|}{ Pendidikan } \\
\hline Tinggi & 28 & $46.7 \%$ \\
\hline Rendah & 32 & $53.3 \%$ \\
\hline \multicolumn{3}{|l|}{ Pekerjaan } \\
\hline Bekerja & 10 & $16.7 \%$ \\
\hline Tidak bekerja & 50 & $83.3 \%$ \\
\hline \multicolumn{3}{|l|}{ Usia } \\
\hline Produktif & 57 & $95 \%$ \\
\hline Tidak produktif & 3 & $5 \%$ \\
\hline
\end{tabular}

Tabel 1 menunjukan bahwa responden yang digunakan dalam penelitian berjumlah 60 responden, diadapatkan prosentase tertinggi pada variable pendidikan rendah $53.3 \%$,tidak bekerja $83.3 \%$ dan usia produktif $95 \%$

\section{Tabulasi silang Pengaruh kelas nenek terhadap keberhasilan ASI Ekkslusif}

Tabel 2. Tabulasi silang Pengaruh kelas nenek terhadap keberhasilan pemberian ASI Eksklusif

\begin{tabular}{|c|c|c|c|c|c|c|}
\hline \multirow{3}{*}{ Kelas nenek } & \multicolumn{4}{|c|}{ ASI eksklusif } & \multirow{2}{*}{\multicolumn{2}{|c|}{ Total }} \\
\hline & \multicolumn{2}{|c|}{ ya } & \multicolumn{2}{|c|}{ tidak } & & \\
\hline & $\mathrm{F}$ & $\%$ & $\mathrm{~F}$ & $\%$ & $\mathrm{~F}$ & o, \\
\hline Dilakukan Perlakuan & 20 & 66 & 10 & 33 & 30 & 1 \\
\hline Tidak dilakukan Perlakuan & 6 & 20 & 24 & 80 & 30 & । \\
\hline & & $t=0$. & & & & \\
\hline
\end{tabular}

Tabel silang menunjukkan bahwa kelompok yang mendapatkan perlakuan kelas nenek, memberikan ASI Eksklusif sejumlah 20 (66\%) dan kelompok yang tidak mendapatkan perlakuan memberikan ASI Eksklusif sejumlah 6 (20\%).

\section{Pembahasan}

Asi eksklusif merupakan makanan terbaik yang harus diberikan kepada bayi sampai usia 6 bulan. Ibu menyusui sudah mendapatkan bekal pengetahuan sejak kehamilan mengenai ASI eksklusif, akan tetapi tantangan yang harus dihadapi saat
Hasil uji chi-scuare antara program kelas nenek dengan pemberian ASI Eksklusif dengan value $0,00<\alpha 0,05$,maka menunjukkan kelas nenek berpengaruh dalam pemberian ASI Eksklusif

menjalankan proses selama 6 bulan kedepan menjadi tantangan yang sangat besar bagi ibu balita .

Permasalahn yang muncul saat menjalankan proses menyusui diantaranya produksi ASI yang kurang, bayi tetap rewel 
dan adanya lingkungan yang menganjurkan bayi segera diberikan makanan pendamping. Permasalahan ASI tidak lancer dapat diatasi dengan dilakukan pijat punggung oleh keluarga sesuai penelitian yang pernah dilakukan sebelumnya yaitu pijat oksitosinmenggunakan minyak essensial lavender (Yuliana, 2016).

Kelompok pendukung ASI eksklusif merupakan wadah partisipasi berbasis masyarakat dalam mengembangkan pembangunan kesehatan di tingkat desa. Kelompok pendukung ASI eksklusif bertujuan untuk meningkatkan kesadaran, kemauan dan kemampuan untuk memberikan ASI eksklusif pada bayinya. Kelompok ini memberikan pengalaman, keterampilan dan peningkatan motivasi ibu menyusui (Widayati, 2015).

Keluarga memberikan peranan yang sangat kuat dalam keputusan untuk tetap memberikan ASI eksklusif. Keluarga adalah bagian dari ibu balita yang paling dekat yang secara tidak langsung akan memberikan penguatan terhadap apa yang menjadi keyakinannnya. Hal ini membutuhkan pendampingan untuk pembekalan pengetahuan yang sesuai sehingga memberikan dukungan untuk mencapai ASI Eksklusif sesuai dengan target (Susilo,dkk.2012).

Masyarakat sudah banyak yang mendapatkan pemahaman tentang pentingnya ASI. Pengetahuan ini tidak banyak merubah perilaku untuk memberikan ASI eksklusif karna tantangan yang dihadapi tentunya berbeda disetiap ibu menyusui. Keluarga yang harusnya memberikan dukungan terkadang tidak tersentuh informasi dalam hal menyusui ASI ekklusif sehingga posisi keluarga dapat menjadi tantangan dalam memberikan ASI eksklusif. Pembentukan kelas dengan mengumpulkan

\section{REFERENSI}

Hidayat, A. A.(2009). Metode Penelitian Kebidanan dan Teknik Analisa Data. Surabaya: Salemba Media

Nursalam. (2008). Konsep Dan Penerapan Metodologi Penelitian Ilmu keperawatan. Edisi 2. Jakarta : Salemba Medika peranan yang sama dapat memudahkan untuk saling sharing dan menguatkan dengan posisi yang sama.

Kegiatan kelompok berupa kelas nenek ini melalui pendampingan kader dan dipantau oleh bidan dapat mensukseskan ASI eksklusif.secara continue dapat dilakukan dan bidan menindaklanjuti ketika ada permasalahn lainnya dari kelas nenek

\section{KESIMPULAN DAN SARAN}

Hasil penelitian adalah kelas nenek efektif terhadap pelaksanaan pemberian ASI Eksklusif.dengan dilakukan kelas nenek pada kelompok control maka banyak ibu yang yang memberikan ASI Eksklusif. Hal ini terjadi karena dukungan nenek sebagai wanita yang paling dekat membuat ibu semakin yakin dengan keputusannya dalam memberikan ASI Eksklusif. Masalah atupun kendala yang dihadapi oleh ibu selama masa menyusui yaitu 6 bulan menjadi lebih ringan ketika nenek ada disampingnya. Nenek juga bisa memberikan solusi yang tepat terhadap permasalahan yang dihadapi oleh ibu.

Saran yang dapat diberikan dari hasil penelitian ini adalah menjadikan kelas nenek sebagai program yang dapat digunakan disetiap desa ataupun setiap posyandu.Tenaga kesehatan dapat melakukan pelatihan untuk kadernya sehingga secara kontinu kegiatan kelas nenek dapat dilakukan disetiap periode sesuai kesepakatan tanpa membuat bidan terjun langsung. Bidan dapat melakukan evaluasi dan pemantauan saja.

Saran bagi peneliti selanjutnya adalah perlu dilakukan penelitian terkait metode yang tepat terkait kelas nenek.

Persatuan Ahli Gizi Indo(PERSAGI). (2017). Penurunan masalah balita stunting. www.depkes.go.id/resources/download/ infoterkini/.../Pakar\%20Stunting.pdf

Susilo, J., Kurdanti, W., \& SiSwati, T., (2012). Hubungan Program Kelompok pendukung ibu terhadap pengetahuan 
dan praktik pemberian ASI Eksklusif. Gizi Indon 2012, 35 (1):30-40:

Widayati, R., \& Wahyuningsih, I. (2015). Pelatihan dan Implementasi Konselor Peer-Support Berbasis Masyarakat pada Kelompok Pendukung ASI Eksklusif. Jurnal STIKES A'isyiyah Surakarta No 1 Nopember 2015, vol 4.
Yuliana, Wahida. (2016). Efektifitas pijat punggung menggunakan minyak essensial lavender terhadap produksi ASI ibu pasca salin. Jurnal Kebidanan dan Keperawatan Stikes 'Aisyiyah Yogyakarta. No.1, Juni 2016, Vol 12. 